Jurnal Keperawatan Silampari

Volume 3, Nomor 1, Desember 2019

e-ISSN :2581-1975

p-ISSN :2597-7482

DOI: https://doi.org/10.31539/jks.v3i1.770

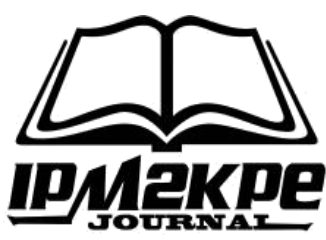

\title{
EFEKTIVITAS METODE EDUKASI AUDIOVISUAL TERHADAP SELF MANAGEMENT PADA PASIEN HIPERTENSI
}

\author{
Fernalia $^{1}$, Busjra ${ }^{2}$, Wati Jumaiyah ${ }^{3}$ \\ Program Studi Ilmu Keperawatan, Stikes Tri Mandiri Sakti Bengkulu ${ }^{1}$ \\ Fakultas Kedokteran, Universitas Muhammadiyah Jakarta ${ }^{2}$ \\ Program Studi Magister Keperawatan, Universitas Muhammadiyah Jakarta ${ }^{3}$ \\ lia_fernalia@yahoo.com ${ }^{1}$
}

\begin{abstract}
ABSTRAK
Penelitian ini bertujuan mengetahui efektivitas metode edukasi audiovisual terhadap self management pada pasien hipertensi. Penelitian ini menggunakan desain quasi eksperiment dengan rancangan non equivalen control group pre and post test, dengan jumlah sampel sebanyak 38 responden yang terdiri dari kelompok intervensi dan kelompok kontrol. Diperoleh hasil adanya perbedaan yang signifikan rata-rata self management kelompok intervensi sesudah dilakukan metode edukasi audiovisual dengan $(p=0,000)$. Tidak ada hubungan antara umur $(p=0,71)$, jenis kelamin $(p=0,955)$ dengan self manajement pada pasien hipertensi. Sedangkan self management akan meningkat setelah dilakukan metode edukasi audiovisual dan dikontrol oleh pengetahuan $(p=0,005)$. Simpulan penelitian ini adalah metode edukasi audiovisual dapat meningkatkan self mangement pada pasien hipertensi.
\end{abstract}

Kata Kunci: Edukasi Audiovisual, Hipertensi, Self Management

\section{ABSTRACT}

This study aims to determine the effectiveness of audiovisual education methods on self management in hypertensive patients. This study used a quasi-experimental design with a non-equivalent control group pre and post test design, with a total sample of 38 respondents consisting of an intervention group and a control group. Obtained a significant difference in the average self-management of the intervention group after the audiovisual education method was performed with $(p=0,000)$. There was no relationship between age $(p=0.71)$, sex $(p=0.955)$ and self-management in hypertensive patients. While self management will increase after the audiovisual education method is carried out and controlled by knowledge $(p=0.005)$. The conclusion of this study is the audiovisual education method can improve self management in hypertensive patients.

Keywords: Audiovisual Education, Hypertension, Self Management 


\section{PENDAHULUAN}

Menurut WHO (2015) Cardiovaskular Disease (CVDs) merupakan penyebab kematian di dunia nomor satu. Pada tahun 2012 sekitar 17,5 juta orang meninggal karena CVD atau $31 \%$ dari seluruh kematian di dunia, dari angka ini 7,4 juta karena penyakit jantung koroner dan 6,7 juta karena stroke. Hal yang lebih memprihatinkan adalah tiga perempat dari kematian akibat CVDs terjadi di negara-negara berpenghasilan rendah. Cardiovascular diseases (CVDs) merupakan sekumpulan gangguan pada organ jantung dan pembuluh darah, yang terdiri dari atas penyakit jantung koroner, penyakit serebrovaskular (stroke), penyakit arteri perifer, penyakit jantung rematik, penyakit jantung bawaan, Chronic Heart Failure (CHF) dan hipertensi.

Hipertensi merupakan keadaan tekanan darah sistolik di atas $140 \mathrm{mmHg}$ dan tekanan darah diastolik diatas $90 \mathrm{mmHg}$ (Smeltzer dan Bare, 2002). Hipertensi juga bisa muncul sebagai efek samping dari obat gagal ginjal dan perawatan penyakit jantung bawaan, kondisi tersebut dinyatakan dengan hipertensi sekunder (Padila, 2012). Hipertensi merupakan salah satu penyebab kematian dini diseluruh dunia, membunuh hampir 9,4 juta orang didunia setiap tahunnya dan keadaan ini terus meningkat. Secara global prevalensi hipertensi diperkirakan mencapai 30\% dari total populasi dan merupakan penyebab kematian sebesar 7,1 juta per tahun (Mortimer, 2011; Andri, 2018). WHO melaporkan bahwa lebih dari 1 miliar orang hidup dengan hipertensi. Pada tahun 2008, prevalensi hipertensi diseluruh dunia pada usia 25 tahun ke atas sekitar $40 \%$. Prevalensi tertinggi terjadi di wilayah Afrika sebanyak 46\%, terendah di wilayah Amerika sebesar 35\%, sedangkan di wilayah Asia Tenggara sebesar 36\% (WHO, 2013).

Di kawasan Asia Tenggara, satu dari tiga orang dewasa mengalami hipertensi. Hampir 1,5 juta jiwa meninggal karena tekanan darah tinggi setiap tahunnya, hal inilah yang menjadikan hipertensi sebagai faktor risiko utama untuk kematian di wilayah Asia Tenggara. Persentase populasi orang dewasa di Indonesia dengan hipertensi meningkat dari 8\% pada tahun 1995 menjadi 32\% pada tahun 2008 (WHO, 2013).

Riset Kesehatan Dasar (RISKESDAS) 2013 mencatat prevalensi hipertensi di Indonesia melalui pengukuran pada usia $\geq 18$ tahun tertinggi di Bangka Belitung $(30,9 \%)$, diikuti Kalimantan Selatan $(30,8 \%)$, Kalimantan Timur $(29,6 \%)$ dan Jawa Barat $(29,4 \%)$. Prevalensi hipertensi di Indonesia yang didapat melalui kuesioner terdiagnosis tenaga kesehatan sebesar 9,4 persen, yang didiagnosis tenaga kesehatan (sedang minum obat) sebesar 9,5 persen. Jadi, ada 0,1 persen yang minum obat sendiri. Responden yang mempunyai tekanan darah normal tetapi sedang minum obat hipertensi sebesar 0,7 persen. Jadi prevalensi hipertensi di Indonesia sebesar 25,8 persen. Sedangkan di provinsi Bengkulu pada tahun 2013 didapatkan data pasien yang terdiagnosa hipertensi sebanyak 21,6\%.

Berdasarkan laporan Kepala Dinas Kesehatan Kota Bengkulu pada tahun 2015 di RSUD Dr. M. Yunus Bengkulu jumlah pasien hipertensi sebanyak 454 pasien yang terdiri dari 93 orang pasien rawat inap dan 361 pasien rawat jalan. Faktor penyebab tingginya prevalensi hipertensi, diantaranya usia diatas 45 tahun, overweight, kurang aktivitas, hiperglikemik, durasi merokok, gangguan mental, status ekonomi, tidak menikah, makan makanan yang tidak sehat (Pradono, 2010).

Akibat hipertensi tidak hanya kebutaan, namun menjadi penyebab utama chronic heart failure (CHF) dan gagal ginjal, resiko komplikasi akan meningkat karena penyakit lain yaitu diabetes melitus. Karena itu hipertensi menjadi faktor risiko utama kematian 
di Asia Tenggara. Menurut Topp \& Frost (2006) ditahun 2030 diperkirakan hipertensi menjadi penyebab kematian di dunia pada usia produktif sebesar $41 \%$.

Tingginya prevalensi hipertensi menyebabkan angka kematian dan resiko komplikasi semakin meningkat dari tahun ketahun, dampak dibidang sosial ekonomi juga akan meningkat. Ini disebabkan karena hipertensi prevalensinya tinggi di wilayah dengan penghasilan rendah dan menyerang usia produktif. Dibutuhkan strategi terintegrasi untuk hipertensi. Strategi diharapkan secara substansial memberikan hasil nyata terhadap penurunan prevalensi, mengurangi resiko komplikasi, dan mengurangi faktor resiko penyakit kardiovaskuler. Penanggulangan hipertensi diharapkan dapat diterapkan secara optimal oleh penderita dan tim kesehatan serta merupakan strategi yang hemat biaya.

Tindakan farmakologis dan non farmakologis adalah strategi dapat dilakukan untuk mencegah dan menurunkan tekanan darah. Menurut The European Society of Hypertension (ESH)/European Society of Cardiology (ESC) (2013) self management hipertensi terdiri dari dua pendekatan utama yaitu modifikasi gaya hidup dan farmakologis. Strategi non farmakologis untuk menurunkan kejadian hipertensi dengan melakukan modifikasi gaya hidup. Ragot et. al., (2005) mengemukan bahwa pasien hipertensi yang melakukan modifikasi gaya hidup untuk mengontrol tekanan darahnya hanya sekitar 30\% dari semua penderita hipertensi. Individu dengan penyakit kardiovaskuler disarankan untuk melaksanakan perawatan diri atau self management sebagai salah satu manajemen penyakit dalam kehidupan sehari-hari (Richard \& Shea, 2011).

Self management hipertensi sangat dibutuhkan agar pasien tidak mengalami penurunan kesehatan dikarenakan penyakit sering berulang. Self management mengarah pada tindakan untuk mempertahankan perilaku yang efektif meliputi penggunaan obat yang diresepkan, mengikuti diet dan olahraga, pamantauan secara mandiri dan koping emosional dengan penyakit yang diderita (Lorig and Holman, 2003). Orem percaya bahwa setiap individu memiliki kemampuan natural dalam merawat dirinya sendiri dan perawatan harus fokus terhadap dampak kemampuan tersebut bagi klien (Simmons, 2009).

Self management dapat terwujud bila seseorang mempunyai perilaku kesehatan yang baik. Perilaku manusia merupakan hasil dari pada segala macam pengalaman serta interaksi manusia dengan lingkungannya yang terwujud dalam bentuk pengetahuan, sikap dan praktek. Sesuai dengan hal tersebut, perilaku kesehatan dapat dirumuskan sebagai bentuk pengalaman dan interaksi individu dengan lingkungannya, khususnya yang menyangkut pengetahuan dan sikap tentang kesehatan. Perilaku aktif dapat dilihat, sedangkan perilaku pasif tidak tampak, seperti pengetahuan, persepsi atau motivasi. Beberapa ahli membedakan bentuk-bentuk perilaku ke dalam tiga domain yaitu pengetahuan, sikap, dan praktek atau sering kita dengar dengan istilah knowledge, attitude, practice (Sarwono, 2009).

Berdasarkan Canadian Hypertension Education Program (2014) rekomendasi terhadap manajemen hipertensi antara lain modifiksi perilaku hidup sehat (aktivitas fisik, mengurangi berat badan, mengurangi konsumsi alkohol, pengaturan diet, pembatasan sodium, diet kalsium dan magnesium, melakukan manajemen stress). Pelaksanaan Self management hipertensi diharapkan dapat menambah pengetahuan pasien terhadap penyakit, memperbaiki sikap dan kepatuhan pengobatan terhadap hipertensi. Hal ini dapat dilakukan dengan pemberian edukasi kepada pasien yang 
mengalami hipertensi. yang bertujuan menurunkan tekanan darah dan faktor resiko hipertensi.

Strategi edukasi audiovisual merupakan media yang menstimulasi indra pendengaran dan penglihatan pada waktu terjadinya proses pendidikan (Notoatmodjo, 2007). Media ini memberikan stimulus pada pendengaran dan penglihatan sehingga hasil yang diperoleh lebih maksimal. Hasil tersebut dapat tercapai karena pancaindera yang paling banyak menyalurkan pengetahuan ke otak adalah mata (75\% sampai 87\%), sedangkan 13 sampai 25\% pengetahuan diperoleh melalui indera lain (Maulana, 2009 dalam Kapti, 2010).

Hasil wawancara perawat di RSUD Dr. M. Yunus Bengkulu diketahui bahwa kemampuan pasien mengontrol tekanan darah masih kurang, menurut perawat tampak dari seringnya pasien kembali datang ke rumah sakit dalam keadaan nilai tekanan darah yang semakin meningkat. Keadaan ini dapat disebabkan beberapa faktor diantaranya kurangnya pengetahuan, kurangnya informasi, kurangnya kesadaran masyarakat terhadap kesehatan atau karena pemilihan metode edukasi penyampaian informasi tentang hipertensi menggunakan metode kurang bervariasi seperti metode ceramah, diskusi yang belum terstruktur, atau leaflet. Media yang menarik dalam edukasi seperti penggunaan media audiovisual terstruktur belum dilakukan. Berdasarkan uraian diatas, menjadi suatu alasan yang penting untuk dilakukan penelitian lebih lanjut terkait efektifitas metode edukasi materi dengan audiovisual terhadap self management pada pasien hipertensi.

\section{METODE PENELITIAN}

Penelitian ini menggunakan metode penelitian kuantitatif dengan desain penelitian Quasi Eksperimental bentuk rancangan "non equivalent kontrol group" (non randomized control group pre-post test) yang bertujuan menyelidiki hubungan sebab akibat dengan memberikan intervensi kepada kelompok eksperimen, kemudian hasil dari intervensi dibandingkan dengan kelompok kontrol, kedua kelompok diukur sebelum dan setelah intervensi. Kelompok intervensi dengan memberikan edukasi audiovisual. Populasi adalah semua pasien hipertensi yang menjalani pengobatan di poli jantung RSUD Dr. M. Yunus Bengkulu. Penentuan jumlah sampel menggunakan tehnik total sampling, dan seluruh sampel dibagi menjadi kelompok intervensi dan kontrol, sampel dibatasi dengan kriteria, diantaranya, inklusi yaitu; (1) bersedia menjadi responden (2) pasien hipertensi (3) pasien tidak mengalami gangguan audiovisual (4) dapat berkomunikasi dengan baik, sedangkan kriteria ekslusi antara lain: (1) pasien yang mengalami keluhan mendadak seperti sesak berat, nyeri kepala hebat (2) pasien yang tercatat melakukan kontrol secara teratur dalam tiga bulan terakhir.

Penelitian dilaksanakan di RSUD Dr. M. Yunus Bengkulu sejak 11 Mei sampai dengan 11 Juni 2016. Alat pengumpulan data menggunakan kuesioner. Kuesioner terdiri atas karakteristik responden: umur, jenis kelamin, tingkat pendidikan. Kuesioner self management hipertensi berisi 16 peryataan tentang: pengaturan diet rendah lemak, diet rendah garam, diet sayur dan buah, aktivitas fisik, manajemen stress, pengaturan berat badan, pembatasan alkohol, kebiasaan merokok, penggunaan pemanfaatan tenaga kesehatan dan kontrol tekanan darah, dan konsumsi obat. Kuesioner menggunakan skala likert diberikan sebelum edukasi audiovisual, edukasi audiovisual diberikan selama 30 menit. Kuesioner akan diberikan kembali satu minggu sesudah diberikan edukasi audiovisual. Pengukuran self management dilakukan dengan dimodifikasi dari Canadian Recommendations for Management of Hypertension (2014) dan 
dikembangankan dari Measuring blood pressure knowledge and self hebaviour of african American, Peters \& Templin (2008).

Analisis pada penelitian ini terdiri dari beberapa tahap. Tahap pertama analisis penelitian menggunakan distribusi frekuensi pada variable umur, jenis kelamin dan pendidikan. Analisis untuk mengetahui pengaruh variabel independen dan dependen menggunakan uji t-test dependent, sedangkan untuk mengetahui pengaruh variabel confounding menggunakan analisis multivariat dengan uji regresi linear.

\section{HASIL PENELITIAN}

Tabel. 1

Distribusi Responden Berdasarkan Umur, Jenis Kelamin, Pendidikan pada Pasien Hipertensi $(n=38)$

\begin{tabular}{lcccc}
\hline \multirow{2}{*}{ Variabel } & \multicolumn{2}{c}{ Frekuensi } & \multicolumn{2}{c}{ Persentase } \\
\cline { 2 - 5 } & $\begin{array}{c}\text { Intervensi } \\
(\mathrm{n}=19)\end{array}$ & $\begin{array}{c}\text { Kontrol } \\
(\mathrm{n}=19)\end{array}$ & $\begin{array}{c}\text { Intervensi } \\
(\mathrm{n}=19)\end{array}$ & $\begin{array}{c}\text { Kontrol } \\
(\mathrm{n}=19)\end{array}$ \\
\hline Umur & & & & \\
$\quad$ Non Produktif & 11 & 8 & 57,9 & 42,1 \\
$\quad$ Produktif & 8 & 11 & 42,1 & 57,9 \\
\hline Jenis kelamin & 14 & 15 & 73,7 & 78,9 \\
$\quad$ Laki-laki & 5 & 4 & 26,3 & 21,1 \\
$\quad$ Perempuan & 5 & 11 & & \\
\hline Pendidikan & 14 & 8 & 26,3 & 57,9 \\
$\quad$ Rendah & & & & \\
Tinggi & & & & 43,3 \\
\hline
\end{tabular}

Berdasarkan tabel 1 menunjukkan bahwa yang menjadi responden pada kelompok intervensi terbanyak berada dalam umur non produktif yaitu 57,9\% (11 orang), sedangkan pada kelompok kontrol umur terbanyak pada usia produktif yaitu 57,9 (11 orang). Responden pada kelompok intervensi terbanyak berjenis kelamin laki-laki sebanyak $73,7 \%$ (14 orang), dan begitu juga pada kelompok kontrol, sebagian besar responden berjenis kelamin laki-laki berjumlah 78,9\% (15 orang). Pada kelompok intervensi responden sebagian besar berpendidikan tinggi 73,3\% (14 orang), dan pada kelompok kontrol responden sebagian besar berpendidikan rendah 57,9\% (11 orang).

Tabel. 2

Distribusi Frekuensi Berdasarkan Skor Self Management Pada Pasien Hipertensi $(n=38)$

\begin{tabular}{lccccc}
\hline \multicolumn{1}{c}{ Variabel } & $\mathrm{N}$ & Mean & SD & Min-Mak & $95 \%$ CI \\
\hline Intervensi & & & & & \\
$\quad$ Sebelum & 19 & 27,11 & 3,557 & $20-35$ & $25,35-28,82$ \\
Sesudah & 19 & 40,37 & 5,946 & $30-50$ & $37,50-43,23$ \\
\hline Kontrol & & & & & \\
\hline Sebelum & 19 & 25,89 & 3,430 & $19-35$ & $24,24-27,55$ \\
$\quad$ Sesudah & 19 & 27,47 & 5,037 & $20-36$ & $25,05-29,90$ \\
\hline
\end{tabular}

Pada tabel 2 didapatkan rata-rata skor self managementpada pasien hipertensi pada kelompok intervensi sebelum perlakuan adalah 27,11 dengan standar deviasi adalah 3,557, skor terendah adalah 20 dan yang tertinggi 35. Dari hasil estimasi interval dapat disimpulkan bahwa $95 \%$ diyakini bahwa rata-rata skor self management pasien hipertensi sebelum perlakuan pada kelompok intervensi antara 25,35 sampai 28,82. Sedangkan sesudah perlakuan nilai rata-rata self management hipertensi adalah 40,37 
dengan standar deviasi 5,946. Skor self management terendah adalah 30 dan skor tertinggi adalah 50. Dari hasil estimasi interval dapat disimpulkan bahwa $95 \%$ diyakini bahwa skor self management hipertensi berkisar antara 37,50 sampai 43,24.

Sedangkan rata-rata skor self management pasien hipertensi pada kelompok kontrol sebelum perlakuan adalah 25,89 dengan standar deviasi adalah 3,430.Skor terendah adalah 19 dan yang tertinggi 36. Dari hasil estimasi interval dapat disimpulkan bahwa 95\% diyakini bahwa rata-rata skor self management pasien hipertensi sebelum perlakuan pada kelompok kontrol antara 24,24 sampai 27,55. Sedangkan sesudah perlakuan nilai rata-rataskor selfmanagement hipertensiadalah 27,47 dengan standar deviasi 5,037. Skor self management terendah adalah 20 dan skor tertinggi adalah 36. Dari hasil estimasi interval dapat disimpulkan bahwa 95\% diyakini bahwa skor self management hipertensi berkisar antara 25,05 sampai 29,90.

Tabel. 3

Perbedaan Rata-Rata Skor Self Managament pada Pasien Hipertensi Sebelum dan Sesudah Metode Edukasi Audiovisual pada Kelompok Intervensi

\begin{tabular}{cccccccc}
\hline Variabel & $\mathrm{N}$ & Mean & SD & $\begin{array}{c}\text { Rerata 95\% } \\
\text { CI }\end{array}$ & $t$ & $d f$ & p value \\
\hline Intervensi & & & & & & & \\
Sebelum & 19 & 27,11 & 3,557 & $-16,123-$ & $-9,744$ & 18 & 0,000 \\
Sesudah & 19 & 40,37 & 5,946 & 10,403 & & \\
\hline
\end{tabular}

Pada tabel 3 menunjukan bahwa rata-rata skor self management kelompok intervensi sebelum metode edukasi audiovisual 27,11 (SD 3,557) sedangkan sesudah diberikan rata-rata skor self management adalah 40,37 ( $\mathrm{SD}=5,946)$. Didapatkan nilai $\mathrm{t}=$ $-9,744, p$ value $=0,000(p<\alpha)$, ada perbedaan yang signifikan antara rata-rata skor self management hipertensi sebelum dan sesudah dilakukan metode edukasi audiovisual pada kelompok intervensi.

Rata-rata self management pada kelompok kontrol sebelum edukasi standar adalah 25,89 ( $\mathrm{SD}=3,430)$, sedangkan setelah edukasi standar 27,47 ( $\mathrm{SD}=5,037)$. Didapatkan nilai $\mathrm{t}=-1,662, \quad p$ value $=0,114 \quad(p>\alpha)$, disimpulkan bahwa tidak ada perbedaan yang signifikan antara skor self management hipertensi sebelum dan sesudah dilakukan edukasi standar pada kelompok kontrol.

Rata-rata skor self management sebelum diberikan metode edukasi audiovisual pada kelompok intervensi 27,11 $(\mathrm{SD}=3,557)$ dan sebelum edukasi standar pada kelompok kontrol 25,89 ( $\mathrm{SD}=3,430)$. Didapatkan nilai $\mathrm{t}=1,068, p$ value $=0,293(p>\alpha)$ maka dapat disimpulkan bahwa tidak ada perbedaan yang signifikan antara skor self management hipertensi sebelum dilakukan edukasi pada kelompok intervensi dengan kelompok kontrol.

Tabel. 4

Perbedaan Rata-Rata Skor Self Managament Hipertensi Sebelum dan Sesudah Edukasi Standar pada Kelompok Kontrol

\begin{tabular}{lccccccc}
\hline \multicolumn{1}{c}{ Variabel } & $\mathrm{N}$ & Mean & SD & $\begin{array}{c}\text { Rerata } \\
95 \% \text { CI }\end{array}$ & $t$ & $d f$ & $p$ value \\
\hline Kontrol & 19 & 25,89 & 3,430 & $-3,575-$ & & & \\
$\quad$ Sebelum & 19 & 27,47 & 5,037 & 0,417 & $-1,662$ & 18 & 0,114 \\
Sesudah & &
\end{tabular}


Berdasarkan tabel 4 menunjukan bahwa rata-rata self management pada kelompok kontrol sebelum edukasi standar adalah 25,89 $(\mathrm{SD}=3,430)$, sedangkan setelah edukasi standar 27,47 $(\mathrm{SD}=5,037)$. Didapatkan nilai $\mathrm{t}=-1,662, p$ value $=0,114(p>\alpha)$, disimpulkan bahwa tidak ada perbedaan yang signifikan antara skor self management hipertensi sebelum dan sesudah dilakukan edukasi standar pada kelompok kontrol.

Tabel. 5

Perbedaan Rata-Rata Skor Self Managament Pasien Hipertensi Sebelum dan Sesudah Metode Edukasi Audiovisual pada Kelompok Intervensi dan Edukasi Standar pada Kelompok Kontrol

\begin{tabular}{cccccccc}
\hline Variabel & $\mathrm{N}$ & Mean & SD & $\begin{array}{c}\text { Rerata 95\% } \\
\text { CI }\end{array}$ & $t$ & $d f$ & $p$ value \\
\hline $\begin{array}{c}\text { Self Management } \\
\text { Intervensi }\end{array}$ & 19 & 27,11 & 3,557 & $\begin{array}{c}-1,089- \\
3,510\end{array}$ & 1,068 & 36 & 0,293 \\
Kontrol & 19 & 25,89 & 3,430 & & & & \\
\hline Self Management & & & & & & \\
Intervensi & 19 & 40,37 & 5,946 & $9,269-$ & 7,212 & 36 & 0,000 \\
Kontrol & 19 & 27,47 & 5,037 & 9,265 & & & \\
\hline
\end{tabular}

Pada tabel 5 menunjukan bahwa skor rata-rata self management pada kelompok intervensi setelah diberikan metode edukasi audiovisual adalah 40,37 ( $\mathrm{SD}=5,946)$ sedangkan rata-rata skor self management setelah edukasi standar pada kelompok kontrol 27,47 ( $\mathrm{SD}=5,037)$. Didapatkan nilai $\mathrm{t}=7,212, p$ value $=0,000(p<\alpha)$ artinya Ho ditolak, ada perbedaan yang signifikan skor self management pasien hipertensi setelah diberikan metode edukasi audiovisual pada kelompok intervensi dan setelah edukasi standar pada kelompok kontrol.

Perbedaan selisih skor self management pada pasien hipertensi pada kelompok intervensi rata-ratanya adalah 13,26 dengan $(\mathrm{SD}=5,933)$. Sedangkan pada kelompok kontrol rata-ratanya adalah 1,58 dengan ( $\mathrm{SD}=4,141)$. Uji statistik didapatkan hasil nilai $p=0.000$ yang berarti ada perbedaan yang yang signifikan pada kedua kelompok tersebut.

Tabel. 6

Analisis Rata-Rata Selisih Skor Self Management Sesudah Dilakukan Metode Edukasi pada Kelompok Intervensi dan Edukasi Standar pada Kelompok Kontrol

\begin{tabular}{cccccccc}
\hline Variabel & $\mathrm{N}$ & Mean & $\mathrm{SD}$ & $\begin{array}{c}\text { Rerata } \\
95 \% \mathrm{CI}\end{array}$ & $t$ & $d f$ & $p$ value \\
\hline $\begin{array}{c}\text { Self Mnagement } \\
\text { Intervensi }\end{array}$ & 19 & 13,26 & 5,933 & $\begin{array}{c}8,318- \\
15,051\end{array}$ & 7,039 & 36 & 0,000 \\
Kontrol & 19 & 1,58 & 4,141 & 15,000 \\
\hline
\end{tabular}

Pada tabel 6 menunjukkan bahwa, perbedaan selisih skor self management pada pasien hipertensi pada kelompok intervensi rata-ratanya adalah 13,26 dengan $(\mathrm{SD}=5,933)$. Sedangkan pada kelompok kontrol rata-ratanya adalah 1,58 dengan (SD $=4,141$ ). Uji statistik didapatkan hasil nilai $p=0.000$ yang berarti ada perbedaan yang yang signifikan pada kedua kelompok tersebut. 
Tabel. 7

Seleksi Bivariat Uji Regresi Variabel Confounding dengan Self Management pada Pasien Hipertensi

\begin{tabular}{lc}
\hline \multicolumn{1}{c}{ Variabel } & $p$ value \\
\hline Umur & 0,129 \\
\hline Jenis Kelamin & 0,955 \\
\hline Pendidikan & 0,005 \\
\hline Bermakna \& masuk kedalam pemodelan $(<0,25)$ &
\end{tabular}

Pada tabel 7 dari analisis seleksi bivariat menunjukkan variabel jenis kelamin memiliki $\mathrm{p}$ value $>0,25$ dan tidak dimasukkan kedalam pemodelan multivariat.

Tabel. 8

Hasil Analisis Pemodelan Awal Multivariat Variabel Independen dan

Variabel Confounding dengan Self management pada Pasien Hipertensi

\begin{tabular}{lccc}
\hline Variabel & $\begin{array}{c}\text { OR Sebelum Variabel } \\
\text { dikeluarkan }\end{array}$ & $\begin{array}{c}\text { OR Setelah Variabel } \\
\text { dikeluarkan }\end{array}$ & $\Delta$ OR \\
\hline Pendidikan & 7,717 & 7,528 & 0,18 \\
\hline
\end{tabular}

Pada tabel 8 diketahui bahwa nilai B pendidikan sebesar 7,528 artinya setiap skor self management pada pasien hipertensi akan naik sebesar 7,528 setelah dikontrol oleh pendidikan.

\section{PEMBAHASAN}

Self management hipertensi merupakan perilaku kesehatan yang didapatkan dari interaksi dengan manusia dan lingkungannya yang terwujud dalam bentuk praktek modifikasi perilaku hidup sehat yang meliputi (aktivitas fisik, mengurangi berat badan, mengurangi konsumsi alkohol, pengaturan diet, pembatasan sodium, diet kalsium dan magnesium, melakukan manajemen stress yang bertujuan menurunkan tekanan darah dan faktor resiko hipertensi Canadian Hypertension Education Program (2014). Penerapan self management hipertensi ini dipengaruhi oleh beberapa faktor, diantaranya pemilihan metode edukasi. Pada penelitian ini metode edukasi audiovisual dipilih sebagai metode dalam penyampaian informasi tentang self management hipertensi, yang dapat digunakan sebagai acuan dalam pelaksanaan self-management hipertensi. Adanya rata-rata perbedaan peningkatan secara positif self management setelah pemberian metode edukasi audiovisual dapat diartikan sebagai hasil dari edukasi kesehatan dengan media audiovisual dan diskusi yang diberikan.

Program edukasi dapat berhasil apabila didukung oleh metode yang baik. Metode merupakan sarana yang digunakan untuk menyampaikan pesan atau informasi yang ingin disampaikan oleh komunikator. Media yang biasa digunakan adalah poster, leaflet, brosur, stiker, dan lembar balik (Mubarak, 2012).

Hasil penelitian ini didukung oleh Flynn, et al., (2013) yang melakukan penelitian tentang efek dari internvensi self management pasien hipertensi. Pada penelitian ini kelompok intervensi mendapatkan pendidikan kesehatan tentang self-management selama 90 menit dengan menggunakan booklet. Hasil dari penelitian ini menunjukkan bahwa pelaksanaan program pendidikan kesehatan menggunakan media yang menarik berupa booklet dapat meningkatkan perilaku self-management hipertensi.

Dapat dijelaskan bahwa pemilihan audiovisual sebagai media penyuluhan kesehatan dapat diterima dengan baik oleh responden. Metode ini menawarkan 
pendidikan kesehatan yang lebih menarik dan tidak monoton. Edukasi dengan audiovisual menampilkan gerak, gambar dan suara sedangkan penyuluhan dengan media cetak menampilkan tulisan dan suara penyuluh secara langsung yang membuat terkesan formal. Maulana (2009) dalam Kapti (2010) media audiovisual memberikan stimulus pada pendengaran dan penglihatan sehingga hasil yang diperoleh lebih maksimal. Hasil tersebut dapat tercapai karena pancaindera yang paling banyak menyalurkan pengetahuan ke otak adalah mata (75\% sampai 87\%), sedangkan 13 sampai $25 \%$ pengetahuan diperoleh melalui indera lain.

Hal ini didukung oleh The Royal Australian College of General Practioners (2010) yang menyatakan bahwa intervensi self management pada orang yang menderita penyakit kronis meliputi kegiatan yang berfokus pada kebutuhan pasien, pengambilan keputusan, pemecahan masalah, manajemen emosional, meningkatkan kemampuan pasien dalam mengelola kondisi penyakit dan menganjurkan pasien untuk aktif dalam pelayanan kesehatan. Beberapa pilihan intervensi yang dapat dilakukan untuk melaksanakan self-management yaitu dengan memberikan edukasi dan informasi dengan menggunakan beragam media, buku pegangan untuk pasien, melakukan wawancara dan memberikan motivasi yang dilakukan oleh penyedia pelayanan kesehatan, dukungan dan motivasi dari teman sebaya, dan pelaksanaan program selfmanagement yang dipimpin oleh orang awam yang dapat memberikan inspirasi, dukungan dan role model bagi pasien.

Hasil penelitian ini sesuai dengan hasil penelitian yang dilakukan oleh Iporra (1996) dengan judul: Educating Hispanic Mothers' Management Of Infant Gastroenteritis, Utilizing Mastery Learning And Overlearning In Conjunction With Audiovisual Instructional Methodsh hasilnya menunjukan adanya perbedaan pengetahuan dan keterampilan responden setelah diberikan metode edukasi audiovisual. Penelitian ini juga sejalan dengan penelitian yang dilakukan oleh Aulia (2014) yang menunjukkan adanya perbedaan peningkatan self managemen pasien hipertensi (jogging, aerobik dan keteraturan mengkonsumsi obat antihipertensi) yang signifikan (Sig. 0,002) setelah diberikan edukasi dengan modul Behavioral Activation antara kelompok intervensi dan kelompok kontrol. partisipan dalam kelompok eksperimen memiliki rata-rata durasi jogging (40,48 menit/hari) dan keteraturan mengkonsumsi obat (6 kali/seminggu) yang jauh lebih tinggi daripada kelompok kontrol.

Hasil penelitian ini juga didukung oleh hasil penelitian yang dilakukan oleh Iso, Shimamoto, et. al., (2010) yang berjudul community-base education for hypertension control yang melibatkan pasien hipertensi berusia 35-69 tahun, dengan jumlah sampel pada kelompok intervensi sejumlah 56 responden dan kelompok kontrol sebanyak 55 responden. Kelompok intervensi mendapatkan pendidikan kesehatan dengan materi dan peragaan yang meliputi tentang pengurangan asupan sodium, susu, gula, kegiatan olahraga seperti jalan cepat, dan pengurangan konsumsi alkohol. Hasil penelitian ini menyatakan bahwa program community-based education pada pasien hipertensi efektif untuk menurunkan tekanan darah dengan cara non farmakologis.

Jadi peningkatan peningkatan self management pada pasien hipertensi sebelum dan sesudah perlakuan pada kelompok intervensi merupakan hasil dari penggunaan metode edukasi audiovisual, karena dengan pemilihan metode yang tepat seperti edukasi audiovisual, responden dapat menangkap informasi lebih efektif karena melibatkan indera penglihatan, serta meningkatkan minat terhadap informasi yang disampaikan yang pada akhirnya informasi tentang self management hipertensi dapat 
teraplikasi dalam praktik keseharian yang hasil akhir diharapkan adalah menekan terjadinya komplikasi.

Berdasarkan hasil uji statistik dapat disimpulkan bahwa tidak ada perbedaan yang signifikan antara skor self management hipertensi sebelum dan sesudah dilakukan edukasi standar pada kelompok kontrol. Hasil ini berbeda dengan rata-rata hasil pada kelompok intervensi yang mengalami rata-rata perbedaan setelah metode edukasi audiovisual. Pendidikan kesehatan merupakan suatu pengalaman pembelajaran yang dirancang untuk memfasilitasi tindakan-tindakan kondusif individu terhadap kesehatan sehingga dapat merawat diri sendiri secara individual atau bersama, berperan sebagai pengambil keputusan untuk merawat kesehatan (Notoatmodjo, 2007). Pemberian pendidikan kesehatan pada kelompok kontrol berupa ceramah antara petugas dan pasien,informasi yang diberikan belum komprehensif dan lebih mengarah pada memberi nasehat. Edukasi juga belum terjadwal dan terstruktur. Edukasi yang berjalan saat ini sebatas saat pasien melakukan kontrol ulang dengan waktu yang tidak terjadwal, sehingga informasi yang dapat disampaikan terbatas, penyampaian informasi juga tidak membatasi seberapa jumlah pasien yang menjadi sasaran.

Pendidikan kesehatan merupakan upaya untuk meminimalkan perbedaan derajat kesehatan akibat ketidaktahuan atau ketidakmampuan dengan pemberdayaan petugas, masyarakat agar mampu memelihara dan meningkatkan kesehatannya. Pemberian pendidikan kesehatan diharapkan menjadi upaya promosi untuk merubah perilaku. Perubahan perilaku kesehatan terbagi dalam 3 dimensi yaitu: mengubah perilaku negatif (tidak sehat) menjadi perilaku positif (sesuai dengan nilai - nilai kesehatan), mengembangkan perilaku positif dan memelihara perilaku yang sudah positif (Notoatmodjo, 2007).

Hasil penelitian sesuai dengan penelitian Saputri (2014) tentang pengaruh metode ceramah dan audiovisual, dari hasil penelitiannya didapatkan hasil perbedaan skor pengetahuan pada kader sebelum diberikan pendidikan metode ceramah rerata $(11,76)$ setelah diberikan pendidikan meningkat menjadi (14,51) dan pada kader sebelum diberikan pendidikan audio visual rerata $(10,33)$ setelah diberikan pendidikan meningkat menjadi $(17,04)$, sehingga ada perbedaan skor pengetahuan kader sebelum dan sesudah diberikan pendidikan kesehatan dengan metode ceramah dan audio visual tentang SADARI. Perbandingan skor pengetahuan kader menggunakan audio visual dan ceramah, audio visual dengan rerata $(6,71)$ lebih besar daripada kelompok ceramah $(2,80)$.

Jadi stimulus yang diberikan dengan metode ceramah pada umumnya hanya dengan suara, padahal stimulus yang maksimal akan terjadi ketika melibatkan indera penglihatan dengan media yang tepat serta menarik, hal ini menyebabkan informasi tentang perawatan yang disampaikan kurang efektif, ditambah dengan belum komprehensifnya informasi yang diterima sehingga hasilnya adalah mayoritas pasien tidak dapat menerapkan self management dengan baik terhadap penyakit hipertensi.

Berdasarkan hasil analisis perbedaan rata-rata skor self management pada kelompok intervensi setelah diberikan metode edukasi audiovisual dan setelah edukasi standar pada kelompok kontrol menunjukkan bahwa metode edukasi yang lakukan pada kelompok intervensi yang mengalami hipertensi dapat meningkatkan self management hipertensi memiliki pengaruh yang positif terhadap pasien. Hasil penelitian ini sesuai dengan Notoatmodjo (2007) bahwa dalam proses pendidikan kesehatan terjadi pengaruh timbal balik antara berbagai faktor, antara lain: subjek belajar, pengajar, metode dan tekhnik belajar, alat bantu belajar dan materi atau bahan yang dipelajari. Sedangkan 
keluaran adalah hasil dari proses belajar, yaitu berupa kemampuan dan perubahan perilaku dari subjek belajar. Metode yang digunakan saat melakukan pendidikan kesehatan juga berpengaruh terhadap peningkatan pengetahuan.

Perbedaan pada kelompok intervensi dan kontrol pada penelitian ini karena media pendidikan kesehatan yang diberikan menggunakan media audiovisual. Organ yang paling banyak menyalurkan pengetahuan adalah mata. Lebih kurang 75-87 \% pengetahuan manusia diperoleh atau disalurkan melalui mata, dan 13-25\% lainnya tersalurkan melalui indra lain. Oleh sebab itu, dalam aplikasi pembuatan media disarankan lebih banyak menggunakan alat-alat visual ataupun audiovisual karena akan mempermudah cara penyampaian dan penerimaan informasi oleh masyarakat (Maulana, 2009). Hasil ini diperkuat dengan adanya penelitian Kapti (2010), menyatakan bahwa pengetahuan dan sikap ibudalam tatalaksana balita dengan diare setelah penyuluhan antara kontrol dan intervensi terdapat perbedaan yang bermakna.

Hasil penelitian ini sejalan dengan Suryani (2008) tentang pengaruh pendidikan kesehatan dengan metode audiovisual tentang cara perawatan bayi terhadap perubahan perilaku ibu primipara dalam perawatan bayi baru lahir. Dalam penelitian ini dilakukan pemutaran video sebanyak satu kali dan menggunakan design one group pre test posttest. Hasil penelitian menunjukkan ada perubahan pengetahuan, sikap dan keterampilan ibu sebelum dan sesudah diberikan penyuluhan melalui media audiovisual. Pada penelitian ini metode yang digunakan adalah berupa tayangan video yang berisi tentang self management pada pasien hipertensi yang dapat digunakan sebagai acuan dalam pelaksanaan self-management hipertensi.

Hasil penelitian ini juga sejalan dengan penelitian yang dilakukan oleh Sanchez, et. al., (2010) dengan judul educational video tool to increase syphilis knowledge among black and hispanic male patients dengan metode randomized controlled trial menggunakan 206 responden menunjukkan hasil uji statistik bahwa pada grup intervensi yang diberi tontonan video edukasi skor pengetahuan meningkat sebesar $24,8 \%$ dibandingkan kelompok kontrol dengan $(\mathrm{p}<, 001)$ artinya ada perbedaan skor pengetahuan tentang syphilis setelah diberi education video. Peningkatan selisih skor self management setelah diberikan perlakuan merupakan akibat dari pemberian pendidikan kesehatan dengan media audiovisual. Dengan demikian media audiovisual sebagai media pendidikan kesehatan efektif digunakan untuk meningkatkan self management menjadi lebih baik. Artinya pemilihan metode edukasi audiovisual akan berdampak positif terhadap nilai skor terhadap pencapaian tujuan peningkatan self management pasien hipertensi.

\section{SIMPULAN}

Dari penelitian ini dapat disimpulkan perbedaan yang signifikan self management pada pasien hipertensi sebelum dan sesudah diberikan metode edukasi audiovisual pada kelompok intervensi, Tidak ada perbedaan antara self management pada pasien hipertensi sebelum dan sesudah edukasi standar pada kelompok kontrol, tidak terdapat perbedaan self management pada pasien hipertensi sebelum edukasi pada kelompok intervensi dan kontrol, ada terdapat perbedaan self management hipertensi pada pasien setelah edukasi pada kelompok intervensi dan kontrol, ada perbedaaan selisih skor self management setelah metode edukasi audiovisual pada kelompok intervensi dengan kelompok kontrol setelah edukasi standar, tidak ada pengaruh umur dan jenis kelamin dengan self management pada pasien hipertensi setelah diberikan edukasi pada kelompok intervensi dan kontrol, ada pengaruh antara variabel pendidikan dengan self 
management pada pasien hipertensi setelah diberikan edukasi pada kelompok intervensi dan kontrol.

\section{SARAN}

\section{Bagi Keperawatan}

diharapkan menggunakan metode edukasi audiovisual untuk meningkatkan self management pasien hipertensi

\section{Bagi Pengembangan Penelitian}

Modifikasi metode edukasi audiovisual dengan metode brainstorming, melakukan penelitian pengalaman metode edukasi audiovisual tentang self management hipertensi, penggunaan lembar observasi responden.

\section{DAFTAR PUSTAKA}

Andri, J., Waluyo, A., Jumaiyah, W., \& Nastashia, D. (2018). Efektivitas Isometric Handgrip Exercise dan Slow Deep Breathing Exercise terhadap Perubahan Tekanan Darah pada Penderita Hipertensi. Jurnal Keperawatan Silampari, 2(1), 371-384. https://doi.org/https://doi.org/10.31539/jks.v2i1.382

Aulia, Muharini. (2014). Validasi Modul Behavioral Activation dalam Meningkatkan Manajemen Diri Pasien Hipertensi di Puskesmas. Tesis

Canadian Hypertension Education Program (CHEP). (2014). Guideline the 2014 Canadian Hypertension Education Program Recommendations for Blood Pressure Measurement, Diagnosis, Assessment of Risk, Prevention, and Treatment of Hypertension. Canadian Journal of Cardiology: Elsevier

ESH/ESC. (2013). Clinical Implications of the 2013 ESH/ESC Hypertension Guidelines: Targets, Choice of Therapy, and Blood Pressure Monitoring. http://www.ncbi.nlm.nih.gov/pmc/articles/PMC4070465/. Diakses tanggal 5 Maret 2016.

Flynn, S. J., Ameling, J. M., HillBriggs, F., Wolff, J. L., Bone, L. R., Levine, D. M. (2013). Facilitators and Barriers to Hypertension Self-Management in Urban African American: Perspectives of Patients and Family Members. Dove Press Limited Country of Publication: New Zealand, 7, 741-749.

Iporra, R. M. (1996). Educating Hispanic Mothers' Management of Infant Gastroenteritis, Utilizing Mastery Learning and Overlearning in Conjunction with Audiovisual Instructional Methods. Http://proquest.umi.com/pqdweb?index= $0 \&$ did $=740432811 \&$ srchmode $=2 \&$ sid $=11 \& f m t=6 \& v i n s t=\quad$ prod $\& v t y p e=$ pqd\&rqt $=309 \&$ vname $=p q d \& t s=1277355925 \&$ clientid $=45625$.

Iso, Shimamoto, Yokota, Sankai, Jacobs, Komachi. (2010). Community-Based Education Classes for Hypertension Control. http://hyper.ahajournals. org/content/27/4/968.full. 27: 968-974. diakses 1 Agustus 2016.

Kapti, Rinik, E. (2010). Efektivitas Audiovisual sebagai Media Penyuluhan dan Sikap Ibu dalam Tatalaksana Balita dengan Diare di Dua Rumah Sakit di Kota Malang. Tesis: Universitas Indonesia.

Lorig, Kate R and Holman, Halsted. (2003). Self-Management Education: History, Definition, Outcomes, and Mechanisms. http://e-resources.perpusnas.go.id: 2057/docview/861217495?pq-origsite=summon. Diakses 26 Februari 2016

Maulana, H. (2009). Promosi kesehatan. Jakarta: EGC

Mortimer. (2011). Effect of Short-Term Isometric Handgrip Training on Blood Pressure in Middle-Aged Females, 22(5). Retrieved from www.cvja.co.za 
Mubarak, W. (2012). Promosi Kesehatan untuk Kebidanan. Jakarta: Salemba Medika Notoatmodjo, S. (2007). Kesehatan Masyarakat Ilmu dan Seni. Jakarta: Rineka Cipta Padila, P. (2012). Buku Ajar Keperawatan Medikal Bedah. Yogyakarta: Nuha Medika Pradono. (2010). Faktor-Faktor yang Mempengaruhi Terjadinya Hipertensi di Daerah $\begin{array}{llll}\text { Perkotaan data } & \text { (analisis }\end{array}$ http://ejournal.persagi.org/go/index.php/Gizi_Indon/article/download/83/80. Diakses 24 Februari 2016

Ragot S., Sosner P., Bouche G., Guillemain J., \& Herpin D. (2005). Appraisal of the Knowledge of Hypertensive Patients and Assesment of the Role pf the Pharmacists in the Management of Hypertension: Results of a Regional Survey. Journal of Human Hypertension. 19: 577-84

Richard, A. A., \& Shea, K. (2011). Delineation of Self-Care and Associated Concepts. J Nurs Scholarsh. 43(3)

Riskesdas. (2013) http://www.depkes.go.id/download. php?file $=$ download/pusdatin /infodatin/infodatin-hipertensi. pdf. Diakses tanggal 24 Februari 2016

Sánchez. (2010). Educational Video Tool to Increase Syphilis Knowledge among Black and Hispanic Male Patients. Journal of Health Care for the Poor and Underserved 2, 371-385.

Saputri \& Emi, Y.F. (2014). Pengaruh Pendidikan Kesehatan dengan Metode Ceramah dan Audio Visual terhadap Pengetahuan Kader tentang Sadari di Kecamatan Baki Kabupaten Sukoharjo. Skripsi http://eprints.ums.ac.id/32327/1. diakses Agustus 2016

Sarwono, S. (2009). Pengantar Psikologi Umum. Raja Grafindo Persada Jakarta

Smeltzer, C \& Bare, B. (2002). Keperawatan Medikal Bedah Brunner \& Sudarth. (Edisi 8) Vol 2. Jakarta: ECG.

Simmons, Laurie. (2009). Dorothea Orem's Self Care Theory as Related to Nursing Pratice in Hemodialisis. Nephrology Nursing journal.

Suryani, B. (2008). Pengaruh Pendidikan Kesehatan dengan Metode Audiovisual tentang Cara Perawatan Bayi terhadap Perubahan Perilaku Ibu Primipara dalam Perawatan Bayi Baru Lahir. http://alumni.unair.ac.id/kumpulanfile/294 829691_abs.pdf

The Royal Australian College of General Practitioners. (2010). Chronic Condition Self Management Guidelines. Summary for Nurses and Allied Health Professionals. Commonwealth Departement of Health and Aging. http://www.nmml.org.au/content/Document/diabetes_divisionsguide.pdf. Diakses 1 Agustus 2016

Topp, R., Frost, K.L. (2006). Exercise for the Inactife Hypertensive Patient. School of Nursing University of Louisville. Ethnicity \& Disease, 16: 27-34

Who/Whd. (2013). High Blood Pressure Global and Regional Overview. http://www.searo.who.int/entity/world_health_day/leaflet_burden_hbp_whd_2013 .pdf?ua=1. Diakses 3 Maret 2016

Who. (2015). Cardiovascular Diseases (CVDs). http://www.who. int/mediacentre/ factsheets/fs317/en/. Diakses 3 Maret 2016 